\title{
Effect of Service Quality and Price on Customer Satisfaction at Kartika Candra in Jakarta
}

\author{
Raden Roro Ayu Metarini \\ Universitas Pamulang \\ Email: dosen00945@unpam.ac.id
}

(Received: march 12-2020; revised: June 12-2020; published: June 30-2020)

\begin{abstract}
This study aims to determine the effect of service quality and price on customer satisfaction at Kartika Candra in Jakarta. The method used was explanatory research with a sample of 96 respondents. The analysis technique uses statistical analysis with regression testing, correlation, determination and hypothesis testing. The results of this study the quality of service significantly influence customer satisfaction by $40.6 \%$, hypothesis testing obtained significance $0,000<0.05$. Price significantly influence customer satisfaction by $40.0 \%$, the hypothesis test obtained significance of $0,000<0.05$. Service quality and price simultaneously have a significant effect on customer satisfaction by $50.3 \%$, hypothesis testing obtained significance $0,000<0.05$.
\end{abstract}

Keywords: Service quality; price; customer satisfaction.

\section{INTRODUCTION}

The development of the hotel business in Indonesia is growing, almost all cities are built by hotels (Attila, 2016; Novicadisa \& Sjamsuddin, 2016; Suardana, Suni, \& Ridwan, 2020). Starting from one-star hotel to five-star hotel. Hotels can grow anywhere, both in large and small cities. At this time the hotel has developed into a very promising business field, where all modern people who go outside the city for work or entertainment are in dire need of lodging or hotel services.

Hotels become one of the main drivers in increasing tourism growth (Mucharreira, Antunes, Abranja, Justino, \& Quirós, 2019; Musavengane, 2019; Zhang, Tu, Zhou, \& Yu, 2020). So the hotel business has a very promising prospect even though in its management it requires large business capital and a lot of labor. However, not a few of the entrepreneurs in Indonesia were tempted and began to invest their capital in the hotel sector in order to obtain the maximum profit as well as providing comfort for hotel guests.

In order to meet the needs of hotel guests, many hotels in Indonesia have been built with several types of hotels that are located in accordance with the needs of hotel guests. The hotel must provide rooms with good, clean and safe so that guests feel comfortable staying, even extending night stay at the hotel (Balaguer \& Pernías, 2013; Chen, 2011). In terms of own hotel room bookings hotel guests can make their bookings directly come to the hotel or indirectly by using information technology such as by telephone, email and website and it cannot be denied if it turns out that the development of information technology at this time also influences the workings of the hotel business this. Where we are required to better understand the 
114 | Jurnal Ilmiah Ilmu Administrasi Publik: Jurnal Pemikiran dan Penelitian Administrasi Publik Volume 10 Number 1, January- june 2020. Page 113-122

developments that occur in the field of technology and information so as to improve the quality of its work.

Many things can affect the back and forth of the hotel business, one of them is how the hotel can attract customers and maintain them by providing the best quality of service so that consumers are satisfied with the services provided by the hotel (Dai, Zhuang, Hsu, \& Huan, 2019; Davras \& Caber, 2019; Nunkoo, Teeroovengadum, Ringle, \& Sunnassee, 2019). In today's business competition, service is the most important thing for both companies to differentiate strategies when they sell the same product. According to (Parasuraman, 1998) states that the quality of service is how far the difference between expectations and reality of customers for the services they receive. The quality of service can be known by comparing customer perceptions of the service that they actually receive with the actual service they expect. Quality of service is the main concern for the company, which involves all of the company's resources. This proves that service quality is a very important aspect that must be considered by the company. Service quality is centered on fulfilling the needs and desires as well as the accuracy of delivery to balance consumer expectations (Anwar, Niswaty, \& Saleh, 2017; Nasaruddin, 2014; Saggaf, Salam, Kahar, \& Akib, 2014; Wahyuni, Akib, \& Darwis, 2017). Services here are all kinds of forms provided by the hotel as long as guests or consumers are in the hotel, including services provided by receptionist, bell boy, room service, security, cleaning service and others. Besides good quality service, facilities also participate plays an important role in attracting consumers.

In addition to service quality, price also influences someone in using hotel services (Balaguer \& Pernías, 2013; Kim, Jang, Kang, \& Kim, 2020; Zhao, Chen, Su, \& Tian, 2019). According to Kotler and Keller (2017) price is the amount of money billed for a product or service, or the amount of value exchanged by customers to get the benefits of owning or using a product or service.

\section{METHOD}

The type of research used is associative, where the aim is to find out the connection between. The population in this study amounted to 96 Kartika Candra respondents in Jakarta. The sampling technique in this study is saturated sampling, where all members of the population are sampled. Thus the sample in this study amounted to 96 respondents. In analyzing the data used the instrument test, classical assumption test, regression, coefficient of determination and hypothesis testing.

\section{RESULT AND DISCUSSION}

In the service business which is engaged in tourism such as hospitality, in addition to providing good facilities to consumers, hotels must also be able to provide an unforgettable experience to their guests so that guests feel satisfied and share their experiences with others so that they can provide positive feedback on hotels. 


\section{Descriptive Analysis}

In this test used to determine the highest minimum and maximum scores, ratting scores and standard deviations of each variable. The results are as follows:

\section{Table 1}

\section{Statistical Descriptive Analysis Results}

\section{Descriptive Statistics}

\begin{tabular}{lr|r|r|r|r}
\hline & N & Minimum & Maximum & $\begin{array}{c}\text { The } \\
\text { mean }\end{array}$ & Std. Deviation \\
\hline Service Quality (X1) & 96 & 32 & 48 & 38.36 & 3,828 \\
\hline Price (X2) & 96 & 30 & 45 & 38.36 & 3,725 \\
\hline Customer Satisfaction (Y) & 96 & 32 & 46 & 39.06 & 3,589 \\
\hline Valid N (listwise) & 96 & & & & \\
\hline
\end{tabular}

Quality of service obtained a minimum variance of 32 and a maximum variance of 48 with a ratting score of 38.36 with a standard deviation of 3.82 8. Prices obtained a minimum variance of 30 and a maximum variance of 45 with a ratting score of 38.36 with a standard deviation of 3.725. Customer satisfaction obtained a minimum variance of 32 and a maximum variance of 46 with a ratting score of 39.06 with a standard deviation of 3.589 .

\section{Multiple Regression Analysis}

This regression test is intended to determine changes in the dependent variable if the independent variable changes. The test results are as follows:

Table 2

Multiple Regression Testing Results

Coefficients $^{\text {a }}$

\begin{tabular}{|c|c|c|c|c|c|}
\hline \multirow[b]{2}{*}{ Model } & \multicolumn{2}{|c|}{$\begin{array}{l}\text { Unstandardized } \\
\text { Coefficients }\end{array}$} & \multirow{2}{*}{$\begin{array}{l}\text { Standardized } \\
\text { Coefficients } \\
\text { Beta }\end{array}$} & \multirow[b]{2}{*}{$\mathrm{t}$} & \multirow[b]{2}{*}{ Sig. } \\
\hline & B & Std. Error & & & \\
\hline 1 (Constant) & 10,158 & 2,991 & & 3,396 & .001 \\
\hline Service Quality (X1) & .378 & .86 & .403 & 4,406 & .000 \\
\hline Price $(\mathrm{X} 2)$ & .376 & .088 & .390 & 4,264 & .000 \\
\hline
\end{tabular}

a. Dependent Variable: Customer Satisfaction (Y)

Based on the test results in the above table, the regression equation $\mathrm{Y}=10.158+$ $0.378 \mathrm{X} 1+0.376 \mathrm{X} 2$ is obtained. A constant of 10.158 means that if there is no service quality and price, then there is a customer satisfaction value of 10.158 points. Service quality regression coefficient of 0.378 , this number is positive, meaning that every time there is an increase in service quality by 0.378 , customer satisfaction will also increase by 0.378 points. Price 
116 | Jurnal Ilmiah Ilmu Administrasi Publik: Jurnal Pemikiran dan Penelitian Administrasi Publik Volume 10 Number 1, January- june 2020. Page 113-122

regression coefficient of 0.376 , this number is positive, meaning that every time there is an increase in price of 0.376 , customer satisfaction will also increase by 0.376 points.

\section{Analysis s Correlation Coefficient}

Correlation coefficient analysis is intended to determine the degree of relationship strength of the independent variables on the dependent variable either partially or simultaneously. The test results are as follows:

Table 3

Correlation Coefficient Testing Results Service Quality on Customer Satisfaction

\section{Correlations $^{\mathbf{b}}$}

\begin{tabular}{|c|c|c|c|}
\hline & & $\begin{array}{c}\text { Kualitas } \\
\text { Pelayanan (X1) }\end{array}$ & $\begin{array}{c}\text { Kepuasan } \\
\text { Pelanggan (Y) }\end{array}$ \\
\hline \multirow[t]{2}{*}{ Service Quality (X1) } & Pearson Correlation & 1 & $.637^{* * *}$ \\
\hline & Sig. (2-tailed) & & .000 \\
\hline \multirow[t]{2}{*}{ Customer Satisfaction (Y) } & Pearson Correlation & $.637^{* *}$ & 1 \\
\hline & Sig. (2-tailed) & .000 & \\
\hline
\end{tabular}

**. Correlation is significant at the 0.01 level (2-tailed).

b. Listwise $\mathrm{N}=96$

Based on the test results obtained a correlation value of 0.637 means that service quality has a strong relationship to customer satisfaction.

\section{Table 4}

Test Results Price Correlation Coefficient on Customer Satisfaction

\begin{tabular}{llr|r}
\hline \multicolumn{1}{c}{ Correlations $^{\mathbf{b}}$} \\
& \multicolumn{1}{c}{ Kepuasan } \\
& Pearson Correlation & \multicolumn{1}{c}{$\begin{array}{c}\text { Kepa (X2) } \\
\text { Pelanggan (Y) }\end{array}$} \\
\hline Price (X2) & Sig. (2-tailed) & 1 & $.632^{* *}$ \\
\hline Customer Satisfaction (Y) & Pearson Correlation & $.632^{* *}$ & .000 \\
\cline { 2 - 4 } & Sig. (2-tailed) & .000 & 1 \\
\hline
\end{tabular}

**. Correlation is significant at the 0.01 level (2-tailed).

b. Listwise $\mathrm{N}=96$

Based on the test results obtained by a correlation value of 0.632 means that prices have a strong relationship to customer satisfaction. 
Table 5

Test Results Correlation Coefficient of Service Quality and Price Simultaneously to Customer Satisfaction

Model Summary

\begin{tabular}{lr|rrr}
\hline Model & $\mathrm{R}$ & $\mathrm{R}$ Square & Adjusted R Square & Std. Error of the Estimate \\
\hline 1 & $.709^{\mathrm{a}}$ & .503 & .493 & 2.556 \\
\hline a. Predictors: (Constant), Price (X2), Quality of Service (X1) & &
\end{tabular}

Based on the test results obtained by the correlation value of 0.709 means that the quality of service and price simultaneously have a strong relationship to customer satisfaction.

\section{Analysis of the Coefficient of Determination}

Analysis of the coefficient of determination is intended to determine the percentage of influence of the independent variable on the dependent variable either partially or simultaneously. The test results are as follows:

\section{Table 6}

Test Results for the Determination of Service Quality Coefficient on Customer Satisfaction

Model Summary

\begin{tabular}{|c|c|c|c|c|}
\hline Model & $\mathrm{R}$ & R Square & $\begin{array}{l}\text { Adjusted R } \\
\text { Square }\end{array}$ & $\begin{array}{l}\text { Std. Error of the } \\
\text { Estimate }\end{array}$ \\
\hline 1 & $.637^{\mathrm{a}}$ & .406 & .400 & 2.780 \\
\hline
\end{tabular}

a. Predictors: (Constant), Quality of Service (X1)

Based on the test results obtained a determination value of 0.406 means that service quality has an influence contribution of $40.6 \%$ on customer satisfaction.

Table 7

Test Results for Price Determination Coefficient on Customer Satisfaction

Summary Model

\begin{tabular}{|c|c|c|c|c|}
\hline Model & $\mathrm{R}$ & R Square & $\begin{array}{l}\text { Adjusted R } \\
\text { Square }\end{array}$ & $\begin{array}{l}\text { Std. Error of the } \\
\text { Estimate }\end{array}$ \\
\hline 1 & $.632^{\mathrm{a}}$ & .400 & .393 & 2,796 \\
\hline
\end{tabular}

a. Predictors: (Constant), Price (X2)

Based on the test results obtained a determination value of 0.400 means that the price has an influence contribution of $40.0 \%$ to customer satisfaction. 
118 | Jurnal Ilmiah Ilmu Administrasi Publik: Jurnal Pemikiran dan Penelitian Administrasi Publik Volume 1o Number 1, January- june 2020. Page 113-122

Table 8

Test Results for Determination Coefficient of Service Quality and Price on Customer Satisfaction

Summary Model

\begin{tabular}{|c|c|c|c|c|}
\hline Model & $\mathrm{R}$ & R Square & $\begin{array}{l}\text { Adjusted R } \\
\text { Square }\end{array}$ & $\begin{array}{l}\text { Std. Error of the } \\
\text { Estimate }\end{array}$ \\
\hline 1 & $709^{a}$ & .503 & .493 & 2,556 \\
\hline
\end{tabular}

a. Predictors: (Constant), Price (X2), Quality of Service (X1)

Based on the test results obtained a determination value of 0.503 means that the quality of service and price simultaneously have an influence contribution of $50.3 \%$ to customer satisfaction, while the remaining $49.7 \%$ is influenced by other factors.

\section{Hypothesis testing}

Hypothesis testing with $\mathrm{t}$ test is used to find out which partial hypotheses are accepted.

Table 9

Hypothesis Test Results The quality of service to customer satisfaction.

Coefficients ${ }^{\text {a }}$

\begin{tabular}{llr|r|r|r|r}
\hline & & \multicolumn{2}{c|}{$\begin{array}{c}\text { Unstandardized } \\
\text { Coefficients }\end{array}$} & \multicolumn{2}{c|}{$\begin{array}{c}\text { Standardized } \\
\text { Coefficients }\end{array}$} & \\
Model & \multicolumn{2}{c}{ B } & Std. Error & Beta & \multicolumn{1}{c}{ t } & \multicolumn{1}{c}{ Sig. } \\
\hline 1 & (Constant) & 16,141 & 2,873 & & 5,619 & .000 \\
\cline { 2 - 8 } & Service Quality (X1) & 597 & .75 & .6018 & .000 \\
\hline
\end{tabular}

a. Dependent Variable: Customer Satisfaction (Y)

Based on the test results on the table above, the value of tcount $>t_{\text {table }}$ or $(8.018>1.661)$ is obtained, thus the first hypothesis proposed that there is a significant influence on the quality of service to customer satisfaction is received.

Table 10

Price Hypothesis Test Results to Customer Satisfaction

Coefficients $^{\mathrm{a}}$

\begin{tabular}{|c|c|c|c|c|c|c|}
\hline \multirow{2}{*}{\multicolumn{2}{|c|}{ Model }} & \multicolumn{2}{|c|}{$\begin{array}{l}\text { Unstandardized } \\
\text { Coefficients }\end{array}$} & \multirow{2}{*}{$\begin{array}{c}\text { Standardized } \\
\text { Coefficients } \\
\text { Beta }\end{array}$} & \multirow[b]{2}{*}{$\mathrm{t}$} & \multirow[b]{2}{*}{ Sig. } \\
\hline & & B & Std. Error & & & \\
\hline & (Constant) & 15.698 & 2.968 & & 5.289 & .000 \\
\hline & Price (X2) & .609 & .077 & .632 & 7.909 & .000 \\
\hline
\end{tabular}

a. Dependent Variable: Customer Satisfaction (Y) 
Based on the test results in the above table, the value of $t_{\text {count }}>t$ table or $(7.909>1.661)$ is obtained, thus the second hypothesis is proposed that there is a significant influence between price on customer satisfaction received. Hypothesis testing with the F test is used to find out which simultaneous hypotheses are accepted.

Table 11.

Hypothesis Test Results of Service Quality and Price on Customer Satisfaction

\begin{tabular}{|c|c|c|c|c|c|c|}
\hline \multicolumn{7}{|c|}{ ANOVA $^{\mathrm{a}}$} \\
\hline & & Sum of Squares & df & Mean Square & $\mathrm{F}$ & Sig. \\
\hline \multirow[t]{3}{*}{1} & Regression & 615.817 & 2 & 307.908 & 47.113 & $.000^{\mathrm{b}}$ \\
\hline & Residual & 607.808 & 93 & 6.536 & & \\
\hline & Total & 1223.625 & 95 & & & \\
\hline
\end{tabular}

a. Dependent Variable: Customer Satisfaction (Y)

b. Predictors: (Constant), Price (X2), Quality of Service (X1)

Based on the test results in the table above, the value of $F_{\text {count }}>F_{\text {table }}$ or $(47.113>2,700)$ is obtained, thus the third hypothesis proposed that there is a significant influence between service quality and price on customer satisfaction is received.

\section{CONCLUSION}

Based on the results of the study it was found that the quality of service has a significant effect on customer satisfaction with a contribution of $40.6 \%$. Hypothesis testing obtained $t$ count $>$ $\mathrm{t}_{\text {table }}$ or (8.018> 1.661). Price has a significant effect on customer satisfaction while contributing $40.0 \%$. Hypothesis testing obtained $t$ count $>t$ table or (7.909>1.661). Service quality and price have a significant effect on customer satisfaction with a contribution of $50.3 \%$ while the remaining $49.7 \%$ is influenced by other factors. Hypothesis test obtained $\mathrm{F}$ count $>\mathrm{F}$ table or $(47.113>2.700)$.

\section{REFERENCES}

Anwar, H., Niswaty, R., \& Saleh, S. (2017). Pelayanan Penerbitan Buku Pelaut Berbasis Online. Jurnal Ilmiah Ilmu Administrasi Publik, 7(1), 11-24.

Attila, A. T. (2016). The Impact of the Hotel Industry on the Competitiveness of Tourism Destinations in Hungary. Journal of Competitiveness. https://doi.org/10.7441/joc.2016.04.06

Balaguer, J., \& Pernías, J. C. (2013). Relationship between spatial agglomeration and hotel prices. Evidence from business and tourism consumers. Tourism Management, 36, 391400. https://doi.org/https://doi.org/10.1016/j.tourman.2012.10.004

Chen, M.-H. (2011). The response of hotel performance to international tourism development and crisis events. International Journal of Hospitality Management, 30(1), 200-212. https://doi.org/https://doi.org/10.1016/j.jihm.2010.06.005

Dai, Y.-D., Zhuang, W.-L., Hsu, S.-Y., \& Huan, T.-C. (2019). Good or bad staff? Hotel 
120 Jurnal Ilmiah Ilmu Administrasi Publik: Jurnal Pemikiran dan Penelitian Administrasi Publik Volume 1o Number 1, January- june 2020. Page 113-122

employees' core self-evaluations impacting service effort and service sabotage considering leader-member exchange moderation. Tourism Management Perspectives, 32, 100564. https://doi.org/https://doi.org/10.1016/j.tmp.2019.100564

Davras, Ö., \& Caber, M. (2019). Analysis of hotel services by their symmetric and asymmetric effects on overall customer satisfaction: A comparison of market segments. International Journal of Hospitality Management, 81, 83-93. https://doi.org/https://doi.org/10.1016/j.ijhm.2019.03.003

Kim, J., Jang, S., Kang, S., \& Kim, S. (James). (2020). Why are hotel room prices different? Exploring spatially varying relationships between room price and hotel attributes. Journal of Business Research, 107, 118-129. https://doi.org/https://doi.org/10.1016/j.jbusres.2018.09.006

Mucharreira, P. R., Antunes, M. G., Abranja, N., Justino, M. R. T., \& Quirós, J. T. (2019). The relevance of tourism in financial sustainability of hotels. European Research on Management and Business Economics, 25(3), 165-174. https://doi.org/https://doi.org/10.1016/j.iedeen.2019.07.002

Musavengane, R. (2019). Small hotels and responsible tourism practice: Hoteliers' perspectives. Journal of Cleaner Production, 220, 786-799. https://doi.org/https://doi.org/10.1016/j.jclepro.2019.02.143

Nasaruddin, H. (2014). Kualitas Pelayanan Kesehatan Di Pusat Kesehatan Masyarakat Kecamatan Pattallassang Kabupaten Gowa. Jurnal Ad'ministrare, 1(1), 28-38.

Novicadisa, S., \& Sjamsuddin, S. (2016). Implementasi Kebijakan Pemungutan Pajak Hotel Kategori Rumah Kos Di Kota Malang. Jurnal Ilmiah Ilmu Administrasi Publik: Jurnal Pemikiran Dan Penelitian Administrasi Publik, 6(1), 69-76.

Nunkoo, R., Teeroovengadum, V., Ringle, C. M., \& Sunnassee, V. (2019). Service quality and customer satisfaction: The moderating effects of hotel star rating. International Journal of Hospitality Management, 102414. https://doi.org/https://doi.org/10.1016/j.ijhm.2019.102414

Parasuraman, A. (1998). Customer service in business-to-business markets: An agenda for research. Journal of Business and Industrial Marketing. https://doi.org/10.1108/08858629810226636

Saggaf, S., Salam, R., Kahar, F., \& Akib, H. (2014). Pelayanan Fungsi Administrasi Perkantoran Modern. Jurnal Ad'ministrare, 1(1), 20-27.

Suardana, W., Suni, M., \& Ridwan, M. (2020). The Influence of Room Prices and Promotion Costs on Hotel Room Occupancy Rates in Palopo City, South Sulawesi. Jurnal Ad'ministrare, 6(2), 123-130.

Wahyuni, N., Akib, H., \& Darwis, M. (2017). Keefektifan Pelayanan Kartu Tanda Penduduk Elektronik (KTP-EL). Jurnal Ilmiah Ilmu Administrasi Publik, 7(1), 1-10.

Zhang, D., Tu, J., Zhou, L., \& Yu, Z. (2020). Higher tourism specialization, better hotel 
industry efficiency? International Journal of Hospitality Management, 87, 102509. https://doi.org/https://doi.org/10.1016/j.ijhm.2020.102509

Zhao, Z., Chen, M.-H., Su, C.-H. (Joan), \& Tian, L. (2019). Asymmetric price responses to hotel competition caused by heterogeneous customers' willingness to pay. International $\begin{array}{llll}\text { Journal of Hospitality } & \text { Management, } & 102409 .\end{array}$ https://doi.org/https://doi.org/10.1016/j.ijhm.2019.102409 
122 Jurnal Ilmiah Ilmu Administrasi Publik: Jurnal Pemikiran dan Penelitian Administrasi Publik Volume 10 Number 1, January- june 2020. Page 113-122 